\title{
Inne emigracje? Spotkania (nie)możliwe polskiej prozy powstającej w Niemczech i w Wielkiej Brytanii
}

Małgorzata Zduniak-Wiktorowicz

TEISTY DRUGIE 2016, NR 3, S. 308-330

DOI $10.18318 /$ td.2016.3.17

W końcu autokar dostojnie zjechał na podziurawione pobocze obskurnej przygranicznej stacji benzynowej i, gdy rozchylił wrota, opróżnił się ekspresowo.' [...]

Zboczyliśmy na małą asfaltową uliczkę, wjechaliśmy do jakiegoś lasku i gdy zobaczyłem w mroku celnika o aparycji rzeźnika, który groźnym halt i sznella zachęcał wszystkich do opuszczenia pojazdu, przypomniałem sobie opowieści babci i dziadków o okupacji, przez które jeszcze do dziś śnią mi się skradające się w gęstwinie lśniące hełmy esesmanów. $^{2}$

Kiedy czytam przywołaną, pierwszą z brzegu, opowieść nowoemigrancką, której bohaterowie są "przyszłymi dumnymi konkwistadorami Wysp Brytyjskich"3,

1 A. Miklasz Polska szkoła boksu. Powieść emigracyina, Skrzat, Kraków 2009, s. 5-6.

2 Tamże, s. 7.

3 Tamże, s. 6.

\footnotetext{
Małgorzata Zduniak-Wiktorowicz - dr, adıunkt w Polsko-Niemieckim Instytucie Badawczym Uniwersytetu im. Adama Mickiewicza i Uniwersytetu Europejskiego Viadrina. Aktualnie kierowniczka grantu „Folski dyskurs postkolonialny i postzaleznościomy a Niemcy" przyznanego przez NCN. Autorka ksiązki Współczesny polski pisarz w Niemczech: doświadczenie, tożsamość, narracja (2010). Kontakt: mzduniak@ amu.edu.pl
} 
odruchowo zestawiam ją z jej poprzedniczką. A jest nią opowieść z początku lat 9 o. ubiegłego wieku:

Potoczyli się wolno wzdłuż kontenerowych skrzyń. Blaszane budy pełniły role kantorów wymiany walut, biur celnych, sklepów, toalet i barów. Ktoś wymalował na nich krzykliwe szyldy i sprawiały teraz wrażenie dekoracji do taniego westernu.

$[\ldots]$

Samochód wjechał na niewielki parking i zatrzymał się w pobliżu pordzewiałego autobusu. Kierowca zgasił silnik. ${ }^{4}$

Nietrudno wyliczyć kolejne podobieństwa przytoczonych fragmentów: ciężka atmosfera, zmęczenie wielogodzinną jazdą, mrok, przystanek, palenie papierosów, przyglądanie się współpasażerom, czyli rodakom. Widać zmęczone, podenerwowane postaci na zgrzebnym tle. Oprócz tego obydwaj autorzy konstruują dopełniające się scenki rodzajowe, charakterystyczne dla miejsc, w których znaleźli się ich bohaterowie; w książce Miklasza będzie to drobny przemyt papierosów: „Na celowniku hurtowo przewożone przez rodaków papierosy. Jedna rama i ani szluga więcej. Rekwirują"5 , zaś u Załuskiego: „Z pozbawionego kół wraka wyszły trzy młode kobiety. Rozchylając długie kożuchy, prężyły skąpo odziane ciała. Miały czarne pończochy i czerwone ręce"6.

Obydwa teksty to opowieści o emigracji, przy czym zestawione wyimki zawierają charakterystyczny i powtarzający się w nich element fabularny poetyki zagranicy - są bowiem o granicy i jej przekraczaniu, o wyjazdach za tę granicę. A co różni te dwie narracje? Zrazu jest to cel podróży: bohaterowie Polskiej szkoty boksu wyjeżdzają na Wyspy Brytyjskie, natomiast protagonista opowiadania Wszyscy jesteśmy obcy, prawie wszyscy przyjezddźa z emigracji do Polski (a był i w Wielkiej Brytanil, i w Niemczech). Jednak ten element tyleż odróżnia obie narracje, co je do siebie upodabnia: w zakończeniu powieści Miklasza, jak u „prawdziwego” emigranta z lat 8o. Załuskiego, też przeczytamy

4 K.M.Załuski Wszyscy jesteśmyobcy, prawie wszyscy, w: tegoż Tryptyk bodeński, Man Gala Press, Sopot 1996, s. 109.

5 A. Miklasz Polska szkoła boksu..., s. 7.

6 K.M. Załuski Wszyscy jesteśmy obcy..., s. 109.

7 M. Zduniak-Wiktorowicz Poetyka zagranicy, w: Przestrzeń jako kategoria poetyki, red. E. Konończuk, E. Sidoruk, Wydawnictwo UB, Białystok 2012, s. 71-85. 
o powrocie głównego bohatera do kraju. Z czynników zewnątrzliterackich zaś trzeba dla porządku wyodrębnić różnicujący oba utwory czas powstania i, co za tym idzie - czas akcji, a także taki fakt z zakresu socjologii literatury emigranckiej, jak rozpoznawalność obu autorów. Adam Miklasz to przedstawiciel licznie dziś piszących o życiu emigrantów zarobkowych w Wielkiej Brytanii, a Krzysztof Maria Załuski reprezentuje tzw. emigrantów posolidarnościowych. Ci drudzy są oczywiście znacznie lepiej rozpoznani w stanie badań9.

\section{Porównania (nie)możliwe}

Zaproponowane zestawienie pokazuje podręczną metodę, za pomocą której czytam prozę emigrancką powstającą od lat 9o. XX wieku w Europie i na świecie. To zestawianie, odnoszenie i porównywanie bierze się z potrzeby śledzenia podobieństw oraz zmian między kolejnymi ogniwami najnowszej literatury, która tematyzuje życie za granicą, a biograficznie (poprzez życiorysy jej autorów i autorek) wiąże się z Polską. Literatura ta bowiem dynamicznie opisuje gwałtownie zmieniającą się i przez to wymagającą rzeczywistość ostatnich lat (nowe podziały społeczno-kulturowe, przebudowa tożsamości jednostkowych i zbiorowych). W tym kontekście zaś emigracja może być traktowana jako doświadczenie o charakterze skrajnie indywidualnym, a przy tym w wysokim stopniu zespołowym czy wręcz zbiorowym. Będąc tak ukształtowaną przestrzenią dla literackich artykulacji, emigracja ewokuje ponadto perspektywę, która jest nie do przecenienia dla nowoczesnej polonistyki przekraczającej granice, a mianowicie - spojrzenie Innego:

8 Zob. W. Ligęza Literatura powrotów. Warianty, w: Polonistyka bez granic, t. 1, red. R. Nycz, W. Miodunka, T. Kunz, Universitas, Kraków 2010, s. 629-638.

9 Zob. m.in.: E. Behring, A. Kliems, H.-Ch. Trepte Grundbegriffe und Autoren ostmitteleuropäischer Exilliteratur 1945-1989. Ein Beitrag zur Systematisierung und Typologisierung, Franz Steiner Verlag, Stuttgart 2004; M. Zduniak-Wiktorowicz Współczesny polski pisarz w Niemczech: doświadczenie, tożsamość, narracja, Wydawnictwo Poznańskie, Poznań 2010; Między językami, kulturami, fiteraturami. Polska literatura (e)migracyina w Berlinie i Sztokholmie po roku 1981, red. E. Teodorowicz-Helmann, I. Gesche, współpraca M. Brandt, Stockholm Slavic Papers 22, Stockholms universitet. Slaviska institutionen, Stockholm 2013; Polnische Literatur in Bewegung. Die Exilwelle der 1980er Jahre, Hrsg. von D. Henseler, R. Makarska, transcript Verlag, Bielefeld 2013; S. Iwasiów Reprezentacje Europy w prozie polskiej XXI wieku, PPH Zapol Dmochowski Sobczyk, Szczecin-Zielona Góra 2013 (partie książki poświęcone prozie B. Helbig, K. Niewrzędy, D. Muszera, I. Rudnickiego). 
To potencjalnie cudze oko umieszczone w moim oku własnym modyfikuje perspektywę patrzenia i treść samych spostrzeżeń: wytrąca je z oczywistości, problematyzuje, uwrażliwia na wartościowanie. ${ }^{10}$

Oczywiście podobną czujność spojrzenia można przypisać wielu prozaikom, również tym, którzy wiodą życie mniej lub bardziej osiadłe, ale nie emigrują. Jak zresztą pisze socjolog badający procesy migracji: „Polacy mają migrowanie we krwi i naprawdę trudno znaleźć ludzi, którzy nie mieliby, w kulturowym sensie, doświadczeń migracyjnych, którzy na określonym etapie swojego życia nie wyjechali albo nie musieli decydować: wyjechać czy zostać?"11. Sądzę jednak, że to właśnie autorzy prozy emigranckiej dzięki swojemu statusowi pomiędzy, życiu w obu kulturach ${ }^{12}$, doskonale wyczuwają i rozpoznają to, co może umknąć nam, zanurzonym na co dzień w kulturze pochodzenia. Nawet gdy jesteśmy w swojej polskości bardzo kosmopolityczni, a przynajmniej gdy lubimy tak o sobie myśleć.

Życie pisarza, który opuszcza jeden kraj i osiedla się w innym, nie odzwierciedla bezkonfliktowego wzbogacenia się o dodatkowy punkt widzenia: „Na ogół zarówno paradygmat kultury, z której się wywodzi, jak i kultury, w której zagościł, jest przez niego poddawany rewizji, postrzegany jako konstrukcja"13. Toteż prozaicy, jak Janusz Rudnicki czy Brygida Helbig (by wymienić dwa najważniejsze i najbardziej dziś rozpoznawalne nazwiska tworzących między Polską a Niemcami), właśnie z cudzoziemska, tj. z dystansem i zaciekawieniem, podchodzą do tego, co dla Polaków swojskie. Wydobywana przez nich egzotyka rzeczywistości obu krajów może być przy tym prezentowana jako coś zagrażającego jednostce (na model prozy Rudnickiego

T. Walas Oko innego/cudzoziemca jako możliwa perspektywa poznawcza literatury polskiej, w: Polonistyka bez granic, s. 213.

11 M.P. Garapich Die Nomaden Europas - polnische Migranten in der Risikogesellschaft , "lahrbuch Polen" 2010, Migration, s. 68 [przeł. - M.Z.-W.].

12 Zob. H.-Ch. Trepte Endstation Deutschland? - Stacja końcowa Niemcy? Czyli in Anioły i świnie (nie tylko) w Berlinie", w: Na chwałę i pożytek nasz wzajemny. Złoty jubileusz Polonicum, red. E. Rohozińska, Wydawnictwa UW, Warszawa 2006, s. 277; M. Zduniak-Wiktorowicz "W szpagacie". Pisarz między Polska a Niemcami, w: Poetyka migracii. Doświadczenie granic w literaturze polskieiprzełomuXXiXXI wieku, red. P. Czapliński, R. Makarska, M. Tomczok, Wydawnictwo UŚ, Katowice 2013, s. 223-234; R. Makarska Między Polskg a Niemcami, między językami. Skrzyposzek, Niewrzęda, Muszer, w: Między ięzykami, kulturami, literaturami, s.330-341.

13 B. Helbig-Mischewski Penis w opałach. Doświadczenia kastracji i strategie odzyskiwania mocy w literaturze kilku migrantów polskich w Niemczech, "Teksty Drugie” 2009 nr 6, s. 160. 
składa się prześmiewcze reprezentowanie swojego i obcego w obu kulturach i wynikające z tego ironiczne konfrontowanie takich postaw - jako zadanie, które sam pisarz na siebie nakłada ${ }^{14}$ ) albo też poddającego się obłaskawieniu i zadomowieniu się w nim (model prozy Helbig, gdzie ironia to na ogół autoironia, a narratorka zapewnia nią sobie przynależność do opisywanego świata gorszych Polaków i Niemców: wcześniej nieudaczników, Enerdowców, ostatnio też „mieszańców”15).

Proza polsko-niemiecka pisarzy średniej generacji (roczniki 5o. i 6o.) tworzy więc punkt odniesienia dla zasygnalizowanych w tytule tego artykułu rozwaźań. Mają one dotyczyć jeszcze nierozpoznanego dobrze wycinka najmłodszej literatury, która czerpie z doświadczenia e-migracyjności w drugiej dekadzie XXI wieku. Nie jest to jednak żadna stabilna płaszczyzna, do jakiej można się odwołać, ponieważ i ona rozwarstwia się na podzbiory, skupiska tekstów nieprzebadane dotąd w równym stopniu. I tak tuż obok prozy wychodzącej spod pióra autorek i autorów średniego pokolenia, którzy żyją i piszą między Polską a Niemcami, powstaje dziś jej następczyni. Jest to rozwijająca się równolegle do pierwszego twórczość drugiego pokolenia emigracyjnego, np. Magdaleny Felixy, Magdaleny Parys, Adama Soboczynskiego, Pauliny Schulz, Alexandry Tobor, czyli autorów młodszych o dwadzieścia, trzydzieści lat. Trzymając się wyróżników biograficznych, dodajmy, że o ile przedstawiciele pierwszej grupy wyjeżdżali do Niemiec na emigrację w początkach lat 8o., o tyle reprezentanci drugiej byli za granicę zabierani przez rodziców lub też rodzili się już w nowym kraju. Ich utwory: Tunel, Das Eiland, Polski Tango, Die Fremde, Sitzen vier Polen im Auto, zaliczylibyśmy więc, jak ujmują tę kwestię zachodni badacze, do literatury postmigrantów ${ }^{16}$. To kategoria, która uwypuklając ów konkretny fakt, że jej reprezentanci wzrastali jako dzieci emigrantów w kontekście migracyjnym (postmigracyjny czynnik biograficzny), przekłada się również na zwartość ich dzieł (topika literacka jako czynnik kategoryzujący w ramach postmigracyjności). Ta bowiem nie wyczerpuje się

14 Widać to dobrze np. w najnowszej książce Rudnickiego Życiorysta, W.A.B., Warszawa 2014 (omówienie m.in.: C. Rosiński janusza R. portret przy książce, „Nowe Książki” $2015 \mathrm{nr} 3$ 3, s. 33).

15 Zob. B. Helbig Niebko, W.A.B., Warszawa 2013 (nowsze omówienie zob.: P. Jasnowski Zabawa w niebko, czyli opowieść o scalaniu tożsamości, "Twórczość" 2015 nr 3, s. 106-108.

16 Nach der Migration. Postmigrantische Perspektiven jenseits der Parallelgesellschaft, Hrsg. von E. Yildiz, M. Hill, transcript Verlag, Bielefeld 2014; M. Geiser Die Fiktion derldentität, Literatur der Postmigration in Deutschland und Frankreich, w: Text und Wahrheit, Hrsg. von K. Bär, K. Berkes, S. Eichler, A. Hartmann, S. Klaeger, O. Stoltz, Frankfurt am Main-Berlin-Bern-Bruxelles-New York-Oxford-Wien 2004, S. 101-111. 
w problematyce migrowania czy, szerzej, globalizacyjnego konfrontowania kultur lub ich hybrydyzacji. Już w wymienionych wyżej utworach odnajdziemy i takie, które po prostu nie rozwijają wątku migracji, co bynajmniej nie wyklucza autorów z tego postmigracyjnego grona twórców nowej literatury wchodzącej w związki z Polską.

Czytając najmłodszą prozę polsko-niemiecką ${ }^{17}$, natrafiamy na jej ciekawe przesunięcia (koncentracja uwagi na identyfikacjach jednostkowych, intymnych) i kontynuacje względem topiki emigranckiej (emigracyjne miejsca, np. obóz dla przesiedleńców; heterostereotypy), ale te i wszystkie inne jej cechy (formy oraz sposoby publikowania, instytucje aktywności kulturalnej i społecznej) należy rozpatrywać z uwzględnieniem całkowicie odmiennych warunków społecznych i kulturowych, jakie modelowały procesy socjalizacyjne przyszłych autorek i autorów ${ }^{\mathbf{1 8}}$. Gdy bowiem Janusz Rudnicki czy Dariusz Muszer odrabiali lekcje prozy ściśle emigracyjnej (wyjazdy, obozy, traumy), by z czasem stać się beneficjentami mobilności czy szerzej globalizacji, Adam Soboczynski (dziennikarz tygodnika "Die Zeit") i Magdalena Parys (absolwentka Uniwersytetu Humboldtów w Berlinie, gdzie chodziła tez na zajęcia z kreatywnego pisania) w tych warunkach dorastali, prędzej i więcej czerpiąc z moźliwości oferowanych im przez życie w kraju imigracji. Nie oznacza to, że da się przeprowadzić jasny podział, w którym emigracyjne traumy przypiszemy tylko prozie pisarzy dziś około pięćdziesięcioletnich, a o czterdziesto- i trzydziestolatkach powiemy np., że opisują stan ich gruntownego przepracowania i obłaskawienia ${ }^{19}$.

17 Zob. B. Helbig-Mischewski, M. Zduniak-Wiktorowicz Inne doświadczenia, inna wiedza? Metodologie narodowe i ponadnarodowe a uciekajgcy przedmiot badań. Rozważania na przykładzie bilateralnego projektu "Najmłodsza generacja autorów polskiego pochodzenia w Niemczech, "Rocznik Komparatystyczny" $2015 \mathrm{nr} 6$ [w druku].

Tym aspektom twórczości najmłodszej generacji pisarek i pisarzy polskiego pochodzenia w Niemczech poświęcone są badania w ramach projektu kierowanego przez Brygidę Helbig-Mischewski i autorkę artykułu: „Migracyjność w zjednoczonej Europie. Narracje pisarek i pisarzy polskiego pochodzenia w Niemczech po roku 1989", finansowanego przez Polsko-Niemiecką Fundację na rzecz Nauki.

Brygida Helbig tak mówi o generacyjnych przeżyciach związanych z opuszczaniem Polski: "Myśmy wyjeżdżali z zamiarem pozostania, a te osoby, które jako dzieci czy nastolatki, tak jak Magda Parys albo Dorota i Emanuela Danielewicz, wyjeżdżały z rodzicami, też wiedziały, że to jest okropne, że żegnają swój kraj, często płakały przerażone, nie chciały wyjeżdżać i czuły, że to, co się w tamtej chwili działo, było straszne" - "Moga mi kiedyś oddać". Rozmowa z Brygidq Helbig, w: Rozmowy na/o granicy. Z Brygidq Helbig, Angelikq Kuźniak, Ingq Iwasiów, Ignacym 
Że niełatwo przeprowadzać tego typu podziały, skądinąd bazujące na takich obiektywnych czynnikach politycznych, jak otwarcie granic i rynku pracy, pokazuje wreszcie proza, która jest trzecim elementem prowadzonych tu rozważań: twórczość emigrantów zarobkowych wyjeżdżających do Wielkiej Brytanii po roku 2004. To rówieśniczka młodego pisarstwa polsko-niemieckiego i podobnie jak ono - czerpiąca $\mathrm{z}$ dobrodziejstw globalizacji, w tym z mobilności przestrzennej jako szansy na wzrost mobilności socjalnej, którą obrazowo nazywamy wspinaniem się pod drabinie społecznej.

Skoro o nowym stuleciu mówi się jako o wieku migracji czy też nowoczesnego nomadyzmu, to refleksja nad jej literackimi świadectwami, również w kontekście śledzenia ścieżek „literatury polskiej w ruchu" ${ }^{20}$, musi uwzględniać teksty tych nowych nomadów Europy. Właśnie o nich, fali emigrantów zaroblkowych, Michał Garapich pisze, że są „,kolejnym rozdziałem historii polskiego migrowania”21 oraz „reaktywują specyfikę polskiej emigracji, rozgałęzionej na kraje, umacniającej emigracyjną topikę i z nią zrywającej, zbiorowej oraz jednostkowej"22.

Warto też wreszcie przywołać fakt zupełnie innej natury, a który również stanowi argument, by zestawiać literaturę powstającą między Polską i Niemcami oraz tę, która bierze się z wyjazdów Polaków do Wielkiej Brytanii. To właśnie te dwa państwa zamieniły się ze sobą miejscami, jeśli chodzi o wybory polskich emigrantów. Według danych przedstawionych w książce Krystyny Iglickiej przed wejściem Polski do Unii Europejskiej 37,5 procent wszystkich emigrujących wyjeżdżało do Niemiec (8 procent do Wielkiej Brytanii, a 1,5 procent do Irlandii), zaś po roku 2004 proporcje te odwróciły się i przedstawiały się następująco: 35,5 procent Polaków wyjechało do Wielkiej Brytanii (9,5 do Irlandii), natomiast do Niemiec 20 procent ${ }^{23}$.

Karpowiczem, Ziemowitem Szczerkiem rozmawiaja Ksymena Filipowicz-Tokarska i Małgorzata Zduniak-Wiktorowicz, red. K. Filipowicz-Tokarska, M. Zduniak-Wiktorowicz, CP i PNIB, Słubice 2014, s. 11.

20 Zob. B. Helbig-Mischewski, M. Zduniak-Wiktorowicz Inne doświadczenia, inna wiedza?...

21 M.P. Garapich Die Nomaden Europas - polnische Migranten in der Risikogesellschaft, "Jahrbuch Polen" 2010, Migration, s. 67. [przeł. M.Z.-W.]

22 Tamże.

23 K. Iglicka Kontrasty migracyine Polski: wymiar transatiantycki, Scholar, Warszawa 2008. Cyt. za: M.P. Garapich Die Nomaden Europas..., s. 68. 
Oczywiście nie da się prosto zestawić warunków życia i pracy twórczej młodych osób polskiego pochodzenia w Niemczech, które chodziły tam do szkoły, z emigrantami zarobkowymi, decydującymi się na wyjazd na Wyspy w połowie pierwszej dekady XXI wieku. Niemniej pisarstwo jednych i drugich ma swoje biograficzne i tematyczne zawiązki w ruchu: możemy go rozumieć m.in. jako swobodę działań ukierunkowaną na wybór tożsamości (np. seksualnej ${ }^{24}$ ), mentalnego uwolnienia od tego, co ją ogranicza, w tym różnych hierarchii i zależności osobistych, rodzinnych, pracowniczych (w tym bezrobocia) etc.

Ale czy przywołany na początku tego artykułu bohater Polskiej szkoły boksu i inne postaci, o których będzie mowa, są w stanie uwolnić się od takich ograniczeń? Już pierwsze sceny powieści Miklasza uświadamiają, że oto emigrujący w gromadzie narrator będzie patrzył na Polaków z dystansu, będzie starał się żyć inaczej niż większość z nich (jest to zresztą przywilej bohaterów sylleptycznych, z którymi autorzy dzielą się własnym dystansem do świata przedstawionego) i w zasadzie dążył, by za granicą uwolnić się od emigracji. Trzeba przyznać, że to fabularny model i historia dobrze znane z najnowszej prozy emigracyjnej, to wciąż, chciałoby się powiedzieć - ta sama historia. Relacje młodych autorów z Anglii czy Irlandii do żywego przypominają etapy życia polskich emigrantów w Niemczech, z tą oczywiście różnicą, że obóz dla tzw. późnych przesiedleńców zmienia się tu w pokój podnajmowany w przeludnionym mieszkaniu o bardzo niskim standardzie czy wręcz w noclegownię dla ubogich.

Może dopiero za kilkadziesiąt lat, może wcześniej, a może dopiero ich urodzone na Wyspach dzieci opowiedzą nam coś innego? Młodzi w Niemczech, którzy emigrację znają z dzieciństwa, dorobili się już własnych opowieści; rozpoznali te, które były udziałem ich rodziców, a to umoźliwia im wypracowywanie własnych - pisanych z zachowaniem większego dystansu i dlatego ciążących ku migracyjności czy wręcz nomadyczności, jaką dostrzega w tej prozie Hans-Christian Trepte ${ }^{25}$.

H.-Ch. Trepte W poszukiwaniu „innej" wolności. Opcja emigracyina, czyli nowoczesny nomadyzm?, w: Opcja niemiecka. O problemach z tożsamościg i historig w literaturze polskiej i niemieckiej po 1989 roku, red. W. Browarny, M. Wolting, współp. M. Joch, Universitas, Kraków 2014, S. 179-195. Zob. też. M. Czarnecki Polacy na Wyspach swingujq częściej, http://wyborcza.pl/duzyformat/1,135755,15353529,Polacy_na_Wyspach_swinguja_czesciej.html (1.03.2015). 


\section{Emigracja i migracja}

Przyjrzyjmy się teraz zasygnalizowanej już w kilku miejscach kwestii klasyfikowania tej literatury w zakresie paradygmatów literaturoznawczych, jakie aktualnie wykorzystuje się do jej opisu. Do dyspozycji mamy dwa: paradygmat emigracyjny i migracyjny, przy czym ten drugi część badaczy postrzega jako naturalnego następcę pierwszego, uznając, że ustała emigracja rozumiana jako konieczność wywiązywania się autorów z obowiązków wobec ojczyzny. Jeśli więc przyjąć, że punktem dojścia refleksji polonistycznej miałaby być na ten czas migracja jako model życia powołujący do funkcjonowania określony typ literatury, to należałoby się zgodzić, że emigracji rzeczywiście już nie ma. Z pomocą w wyjaśnieniu tej kwestii przychodzi poetyka migracji - pojęcie i metoda lektury zaproponowane przez Przemysława Czaplińskiego we wstępie do tomu o tym samym tytule, który przepatruje zajmującą nas tu literaturę „spomiędzy"26.

Jednak empiria tekstów literackich, których dotyczy ten rodzący się w łonie polonistyki dyskurs migracyjny, stoi niekiedy w sprzeczności z traktowaniem poetyki migracji jako jedynego paradygmatu adekwatnego do nowych czasów i nowej literatury o wyjazdach za granicę. Jeśli bowiem z perspektywy badań skupionych na związkach polsko-niemieckich spojrzymy na najnowszą prozę powstającą w Anglii czy Irlandii po wstąpieniu Polski do Unii, okaże się, że odejście od starych konceptów nie zawsze jest moźliwe; i to w sytuacji, gdy mamy do czynienia z pierwszą falą tzw. prawdziwych migrantów w najnowszej historii Polski. Zawartość problemowa i kształt narracyjny (tradycyjna emigracyjna opowieść trójstadialna: wyjazd z kraju, zamieszkanie w nowym miejscu, nie/wrastanie w nie) wielu opowiadań i powieści, które tworzą korpus tekstów badanych w ramach projektu "Polska literatura (e) migracyjna w Irlandii i Wielkiej Brytanii po roku 2004", uprzytamnia, że przekraczanie mentalnej granicy polskiego kompleksu bywa bardzo trudne. Potrzeba ciągłego sytuowania się wobec kraju pochodzenia i kraju pobytu, porównywania się i konfrontowania jako cecha odautorskich postaci wciąż tworzy "napięcie emigranta"27.

Podobnie "negatywnie" modeluje zarysowaną powyżej sytuację badawczą proza młodych pisarek i pisarzy (roczniki 70. i 80.) powstająca w Niemczech. Są w niej świadectwa zmiany paradygmatu, nowe formy

26 P. Czapliński Kontury mobilności, w: Poetyka migracji..., s. 9-42.

27 Wszystkim się wydaje, że śmierć jest zawsze ważnjejsza od życia. Rozmowaz Ingq Iwasiów, w: Rozmowy nalogranicy, s. 40-41. 
wyrazu i odmienne biogeograficzne warunki jej powstawania, ale są też dowody nieustępowania emigracyjności dziedziczonej po rodzicach ${ }^{\mathbf{2 8}}$. Niemniej założenia poetyki migracji jako zespołu „elementów i ich kombinacji swoistych dla pewnego korpusu dzieł"29 problematyzując status migranta jako człowieka żyjącego w zglobalizowanym świecie, pokazują, że migrant nie jest żadną radosną reinkarnacją emigranta z lat 8o., który wyjeżdżał, bo musiał. Polski migrant traktowany jak pewien prototyp literacki (emigrant byłby więc postacią archetypiczna) też często musi wyjechać, ale - inaczej niż jego poprzednik - może to zrobić dużo łatwiej. Również migrant ma swoje traumy, przed którymi migracja ciążąca w niektórych ujęciach ku wolnemu ruchowi, nomadyzmowi, nijak nie chroni. Dodajmy wreszcie, że dostrzegając istotę zmian w zakresie globalnego przepływu osób, co wymaga stosowania pojęcia migracji jako metafory kondycji współczesnego człowieka, nadal powiemy o bohaterach prozy z Wysp - że żyją na emigracji.

Być może więc w odniesieniu do rodzimych realiów emigracyjność i migracyjność jako cechy literatury byłyby swoimi wariantami? A może, uznawszy prymat globalnych zmian kulturowych, należałoby raczej powiedzieć, że emigracja jest inwariantem migracji? Ilekroć bowiem emigracja pojawia się jako zespół charakterystycznych, rozpoznawalnych cech utworu literackiego, nie zmienia przecież swojego charakteru, ale jednocześnie doposaźa literaturę migracyjną, pozostając jej emigracyjną twarzą.

Dlatego też trudno na razie jednoznacznie potwierdzić, że w najnowszej literaturze polskiej nie mamy już do czynienia z emigracją jako rodzajem wielkiej społecznej narracji. Choć trudno teź nie przyznać racji badaczowi, który twierdzi, że emigracyjność to w gruncie rzeczy sprawa indywidualna:

Właściwie już nie wiadomo, kto się obecnie czuje emigrantem, migrantem lub nowoczesnym nomadą. Taka definicja zależy przede wszystkim od osobistego punktu widzenia, od konkretnych poglądów i doświadczeń danego pisarza lub danej pisarki. ${ }^{30}$

M. Zduniak-Wiktorowicz "Inny to ten, który właśnie siedzi w aucie". Prozatorski debiut Alexandry Tobor a nowe pokolenie piszących o Polsce w Niemczech, "Studia Germanica Gedanensia" 2014 nr 30, s. 80-93.

P. Czapliński Kontury mobilności, w: Poetyka migracji..., S. 40. 


\section{Co może e-migrant?}

W tym kontekście poetyka migracji jako konceptualizacja o „ruchomych perspektywach" ${ }^{31}$ otwiera się na działania komparatystyczne ${ }^{32}$ ze strony badaczy innych literatur pokolenia migracji. Ponadto odsyła ona do ,autokreacyjnego charakteru samej migracji", który polega na tym, że migrant cały czas stara się stwarzać samego siebie: począwszy od wyglądu, przez to, jak mówi w obcym języku, po etapy kariery stanowiącej stały punkt odniesienia dla pisania narracyjnej toźsamości odautorskiego bohatera w wymiarze psychologicznym i literackim. W takich warunkach proza, która chciałaby dotrzymać tempa migrantowi w ruchu, nie może spełnić się tylko w realistycznym, drobiazgowym odrysowywaniu tego, czym migrant żyje, w przenośni i dosłownie - czyli co je, pije, ile zarabia, gdzie pracuje, jak wspomina wyjazd, co myśli o Polakach i Niemcach albo o Brytyjczykach. Migrant jako pisarz, w naszym przypadku często początkujący, sięga więc po strategie uatrakcyjniające.

W odniesieniu do średniej generacji autorów migrujących Helbig-Mischewski pisała: „Doświadczenie migracyjne na planie poetologicznym łączy się z upodobaniem do ironii, autoironii, absurdu, humoru, groteski [...]"33. Ich twórczość pełna jest różnych odcieni humoru gwarantowanego choćby wariantami powieści łotrzykowskiej jako formy chętnie branej na warsztat przez Muszera czy Rudnickiego.

Natomiast nowego, młodego migranta, ową sylleptyczną postać zatrzymaną w kadrze wielu nowych polskich artykulacji literackich zobaczymy w takim tekstowym otoczeniu, które wytwarza klimat niemożliwego. „Niemoźliwe" to w tym ujęciu: niesamowite wydarzenia (np. ze sfery nadprzyrodzonej, przywoływanej przeszłości, koszmarnego snu), dziwne, niepokojące, budzące emocje postaci (przysłowiowi „źli ludzie”, demony, szaleńcy, pogodzeni z losem widzący więcej mędrcy, którzy skrywają swoje straszne tajemnice, odszczepieńcy oraz osoby o podwójnej tożsamości, np. seksualnej) i formy opowieści, które mają przenosić znaną, często uprzednio już rozpoznaną przez emigrantów, tożsamościową opowieść w przestrzeń, gdzie wszystko może się zdarzyć.

Dzięki takim sposobom ujmowania świata migranckiego dziecięca trauma wyjazdu z Polski do Niemiec zamieni się w kolorową bajkę, a młody polski

31

32

33

P. Czapliński Kontury mobilności, w: Poetyka migracji.., s. 40-42.

Zob. R. Nycz Możliwa historia literatury, w: Na pograniczach literatury, red. J. Fazan, K. Zajas, Universitas, Kraków 2012, s. 13-34.

B. Helbig-Mischewski Penis w opałach.., s. 162. 
pakowacz pracujący przy taśmie w Anglii zbije majątek na czarnej magii. To, co rzeczywiste i dla emigracji oczywiste, zostaje więc doświetlone niesamowitym. Ciekawe, że właśnie taką zbieżną strategię realizują au torzy należący do obu przedstawianych grup.

O ile bowiem w utworach Magdaleny Parys (Tunel, Magik), Pauliny Schulz (Das Eiland), Sabriny Janesch (Katzenberge, Ambra) oraz Jana Krasnowolskiego (Afrykańska elektronika), Adama Miklasza (Polska szkoła boksu), Konrada Jaskólskiego (Kalendarz Easy Ridera) czy Tomasza Kwiatkowskiego (Krychazrodu Dawida - Londyn. Dwa Amsterdamy) mamy do czynienia ze wspomnianymi, odmiennymi doświadczeniami formacyjnymi autorów (wyjazd z rodzicami do Niemiec Zachodnich i samodzielny wyjazd na emigrację zarobkową na Wyspy), o tyle uwage zwraca wykorzystywanie przez jednych i drugich literackiej konwencji (nie) możliwego, niespotykanej dotąd na szerszą skalę w polskiej prozie z tego klucza.

\section{Gatunki i formy niemożliwego}

$\mathrm{Na}$ poziomie gatunku uruchamianie owej konwencji widać w sięganiu po formy popularne. Tak określone wybory młodych autorów rzucają światło na ich podejście do literackości; gatunkowość jest w tym kontekście pierwszym i głównym znakiem rozpoznawczym tego, co literackie, i polega na grze pisarza, tworzącego fikcję, z czytelnikami, którzy w tej grze uczestni$\mathrm{czą}^{34}$. Stąd w korpusie tych tekstów odnajdziemy m.in.: thriller polityczny (Tunel Magdaleny Parys), powieść kryminalną (Magik tej samej autorki), thriller przechodzący w horror (opowiadania z tomu Afrykanska elektronika Jana Krasnowolskiego) czy powieść obyczajowo-sensacyjną (Polska szkoła boksu Adama Miklasza). Oto więc migracyjne doświadczenie tych autorów i ich postaci zostaje włączone w taki typ narracji, który ze swej gatunkowej natury ma za zadanie angażować odbiorcę na poziomie afektów związanych ze śledzeniem biegu wydarzeń. Wszelkie, liczne zwroty akcji czerpią zaś jednocześnie: $z$ realiów życia migranckiego w Niemczech i na Wyspach Brytyjskich oraz z konwencji niemożliwego wykorzystywanej w ramach literatury popularnej. Wyrazistym przykładem łączenia obu tych planów jest proza Magdaleny Parys, która w swoich dwóch wydanych jak dotąd powieściach chce rozbudzić zainteresowanie czytelników współczesnymi

34

\footnotetext{
R. Sendyka W stronę kulturowej teorii gatunku, w: Kulturowa teoria literatury. Glówne pojęcia
} iproblemy, red. M.P. Markowski, R. Nycz, Universitas, Kraków 2006, s. 256-257. 
Niemcami. By ją pobudzić, koncentruje się na tajemnicach - tę funkcję pełnią tzw. ciemne momenty i zdarzenia z najnowszej historii tego kraju, który przez wiele powojennych lat pisał swoje osobne, ale powiązane rozdziały. Co w tym kontekście ciekawe, sama przyznaje się do fascynacji faktami owianymi tajemnicą. W wywiadzie udzielonym „Wysokim Obcasom" na pytanie Katarzyny Surmiak-Domańskiej: „Dlaczego Magik?”, odpowiedziała: „Zaczęło się od tego, że w 2008 roku przeczytałam w «Der Spiegel» reportaż o śmierci pewnego chłopaka z NRD - Michaela Webera. Miał 19 lat i chciał być wolny. Zginął w lipcu 1989 roku w Bułgarii, 150 m od granicy z Grecją" ${ }^{35}$, dodając:

Ta historia tak mnie wciągnęła, że zaczęłam śledzić artykuły i wywiady z Appeliusem [niemiecki politolog, który badał sprawę zniknięć, zabójstw uciekinierów z NRD, przez Bułgarię, na Zachód - M.Z.-W.]. Okazało się, że w latach 1964-89 granicę w Bułgarii próbowało sforsować ponad 4,5 tys. mieszkańców demoludów. Większość z NRD. Mniej więcej trzem osobom na sto to się udawało. Inne wracały do domów, gdzie czekały ich procesy i odsiadka. Ponad sto osób zostało zastrzelonych, to byli zwykle młodzi ludzie. Ich ciała często zostawiano na miejscu. Gniły - albo pożerały je zwierzęta. ${ }^{36}$

$\mathrm{Na}$ bazie tego typu autentycznych wydarzeń (w Tunelu ${ }^{37}$ chodziło o budowę podziemnego korytarza dla uciekinierów z Berlina Wschodniego do Zachodniego) Parys pisze m.in. o tym, jak w powojennych oraz pozjednoczeniowych Niemczech naziści i komuniści robili polityczno-finansowe kariery, często po trupach. W jej utworach dochodzi więc do klasycznego starcia sił złego i dobrego, a to ostatnie reprezentowane jest przez zwykłych Niemców, ofiary zbrodniczego systemu i działań agentów Stasi, oraz Polaków - jak Magda w Tunelu. Równieź bohaterka Magika, dziarska dziennikarka Dagmara Bosch (wcześniej Boszewska), w pełni zsocjalizowana emigrantka, to ofiara dawnej wschodnioniemieckiej polityki matactw i zbrodni: w latach 80 . traci ojca, a trzydzieści lat później w związku z tą samą sprawą - ojczyma, z którym

35 Wszędzie gdzie jest o przekraczaniu granic, jest też o mnie, http://www.wysokieobcasy.pl/wysokie-obcasy/1,53662,16918762,Magdalena_Parys__Wszedzie_gdzie_jest_o_przekraczaniu. html (1.03.2015).

36 Tamże.

37 M. Parys Tunel, Świat Książki, Warszawa 2011. 
matka związała się w Niemczech na emigracji wymuszonej zagadkową śmiercią pierwszego męża. Wielka historia w odsłonie polsko-niemieckiej wciąga i krzywdzi bohaterów nawet po końcu tak wielkich narracji, jak komunizm i walka z nim:

Matka miała mniej masy i fason trzymała słabiej. Zbierał się w niej żal, bo to nie ona drukowała gazetki, nie ona wypisywała na murach demonstracyjne hasła, nie ona przemycała maszyny i taśmy przez granicę. [...] Wina zbiorowa, rodzinna, jakakolwiek wina w Polsce Ludowej była już winą samą w sobie, a jak jest wina, to musi być i kara. Do demokracji droga była daleka i niepewna, choć słowa papieża: „Niech zstąpi Duch Twój i odnowi oblicze ziemi. Tej ziemi!" już padły, siejąc ziarno, ale ziarno wtedy wolno rosło. Jak się czeka, to nic nie rośnie, $\mathrm{z}$ daleka to rośnie, z bliska słabiej.

$[\ldots]$

- Mamo! - zadrżałam, nie mogąc opanować łez i rozpaczy. - Ja nie wyjeżdżam, JA zostaję! Rozumiesz? Zo-sta-ję! ${ }^{38}$

Emigracyjne losy pokolenia rodziców Dagmary odpowiadają czasowo wyjazdowi z Polski samej Parys, która jako nastolatka w roku 1984 razem z matką zamieszkała w Berlinie Zachodnim. Informacje na temat życia w Polsce, jej społeczno-gospodarczej sytuacji (w Magiku jest mowa m.in. o dorabianiu na handlu w demoludach czy wiecznych staraniach o paszport), jak i realia podzielonego miasta (vide Tunel) odsyłają bezpośrednio do losów Polaków emigrujących „za komuny". Po ten właśnie czas i jego prototypowe postaci, skądinąd bardzo dobrze znane elementy świata przedstawianego w utworach emigracyjnych pisarzy średniego pokolenia, sięga autorka postmigracyjna. Znakiem rozpoznawczym swojej literackiej metody czyni poetykę thrillera politycznego i kryminału. Taki jest jej pomysł na wejście do świata literackiego (debiutowała w roku 2011).

Zbliżona pod względem strategii pisarskich jest proza Jana Krasnowolskiego, emigranta tworzącego w Bournemouth nad Kanałem La Manche. On także wykorzystuje formy gatunkowe pełne niejasności i niemoźliwego, ale posuwa się w tym względzie nieco dalej niż Parys, ponieważ operuje poetyką horroru. U fabularnych podstaw opowiadania Afrykańska elektronika również, jak w Tunelu i Magiku, leży starcie dobra i zła. Jednak stosownie do własnej 
sytuacji Krasnowolski łączy je z realiami życia Polaków pracujących na Wyspach, np. w fabryce perfum:

[...] nie wszyscy są w porządku, a niektórzy to stuprocentowe buce. Chociażby taki Grześ od szredera. Szreder to wielka maszyna do zgniatania śmieci, a Grześ ją obsługuje. Codziennie obchodzi cały zakład, opróżnia kontenery, segreguje śmieci, a potem wrzuca je do swojego szredera, który mieli wszystko na miazgę. [...] Grześ to ryży cwaniaczek z wąsikiem z zabitej dechami dziury gdzieś na Rzeszowszczyźnie. Przemądrzał taki, gdzie to on nie był, czego nie widziat! ${ }^{39}$

W opowiadaniu poznajemy więc codzienność emigrancką, a w niej przeciętnych emigrantów, którzy wdają się w różne przepychanki. Do tego swojskiego klimatu polskiej swarliwości zostaje włączony jednak nowy, obcy kulturowo element. Do tekstu wnosi go bezpośrednio postać Toma Ubijee, wychowanego w Anglii emigranta z Ghany, „koleżki co stoi obok mnie, przy taśmie w fabryce"40. Tom, chcąc pomóc narratorowi w konflikcie z Grzesiem, wykorzystuje siły wudu. Jego pomoc jest tyleż skuteczna, co makabryczna, ale wkrótce koledzy zakładają spółkę wymierzającą sprawiedliwość na prośbę innych pokrzywdzonych. Prędko dorabiają się wielkich pieniędzy, ale równie szybko rzecz wymyka im się spod kontroli. Czarna magia uruchomiona w stużbie interesownie traktowanego dobra pokazuje swój niszczący rewers: zwykłe życie młodych emigrantów po krótkim okresie prosperity staje się koszmarem. Narratora trapią lęki we śnie i na jawie, przeczuwa, że nadciąga coś bardzo złego, na Toma z kolei bardzo gniewają się zmarli przodkowie:

- Za późno - mówi smutno Tom. - Duchy przodków się rozgniewały. Próbowałem je ułagodzić, przebłagać, ale nie chcą mnie już słuchać... Krztusi się nagle, zanosi okropnym kaszlem, a potem wypluwa na podłogę okropny skrzep krwi. Na jasnych deskach podłogi ciemnieje teraz krwawy glut i widzę, że coś w nim pulsuje, rusza się. [...] Chce powiedzieć coś jeszcze, ale głos grzęźnie mu w gardle. Widzę, jak spomiędzy jego warg wysuwa się mała czarna żmijka, cienka jak ołówek, z trójkątną

39 J. Krasnowolski Afrykańska elektronika, w: tegożAfrykańska elektronika, Korporacja Ha!art, Kraków 2013, s. 70.

40 Tamże, s. 69. 
główką, z rozdwojonym językiem. Spada na ziemię, syczy wściekle. Teraz z ust Toma wyskakują następne, dosłownie dziesiątki małych czarnych żmij. Kłębią się wokół niego w kałuży śluzu, kąsają go po całym ciele. ${ }^{41}$

W tym kontekście nieco bardziej realne problemy ma narrator Afrykańskiej elektroniki, który musi uciekać przed islamskimi fanatykami. Jednak scena jego ucieczki samochodem przypomina film sensacyjny, a w zasadzie wręcz thriller.

Niemożliwe i niesamowite widać tu więc w konstrukcji tekstu w ramach lad lit ${ }^{42}$, ale również - uwzględniając topikę emigrancką - w formach wychodzenia poza własną kulturę, dobrze rozpoznaną przez pisarzy tworzących za granicą. Podobnie pod tym właśnie względem rozgrywają się wypadki w Polskiej szkole boksu Adama Miklasza, gdzie narrator powie: „Ja, prosty emigrant, znałem największą tajemnicę lokalnego króla świata przestępczego i byłem pewien, że muszę się mieć na baczności" "43. Wątek sensacyjny funduje tu fakt, że polscy emigranci w Buckby nieopatrznie wchodzą w na teren gangu Albańczyków ze strasznym Mustafą na czele; stąd też w powieści sceny gróźb, bójek ulicznych i spektakularnych ucieczek. Warto jednak dodać, że podłoże tego konfliktu ma prawdziwie emigracyjny i w tym sensie dojmujący charakter: Polacy wkraczają na nie swój teren podczas łowów z tzw. wystawek, czyli zbierania w bogatych dzielnicach niezniszczonych sprzętów, które następnie można korzystnie sprzedać. W obu książkach różniących się pod względem nasilenia pierwiastka niesamowitego (horror Krasnowolskiego, sensacja Miklasza) autorzy dotykają jednakże podobnego problemu - jest nim naruszanie takich zakazów kulturowych jak nieczynienie zła - czy to zabijanie, kradzież czy też donosicielstwo. W jednym i drugim przypadku okazuje się, że emigracja może te zasady zawiesić.

Z łamaniem tabu mamy do czynienia także w prozie migrantek polsko- niemieckich. Już pierwsze sceny opowiadania Das Eiland Pauliny Schulz ${ }^{44}$ i powieści Katzenberge Sabriny Janesch ${ }^{45}$ zawierają informacje o śmierci

41 Tamże, s. 108-109.

42 Wydawca informuje na okładce, że „opowiadania Krasnowolskiego zalicza się do lad lit, czyli popularnej literatury przeznaczonej głównie dla męskiego odbiorcy".

A. Miklasz Polska szkoła boksu..., s. 255.

P. Schulz Das Eiland, freiraum-verlag, Greifswald 2014.

S. Janesch Katzenberge, Aufbau Verlag, Berlin 2010. 
członków najbliższej rodziny głównych bohaterów (ojca i dziadka), niejako w ślad za tym idzie więc narracja, w której zdani na siebie bohaterowie, każdy na swój sposób, odkrywają stabuizowane tajemnice domowe. John w Das Eiland raz po raz mówi coś symptomatycznego dla wszechobecnego w tym opowiadaniu klimatu napięcia: „To jak bardzo się wtedy myliłem, stawało się jasne w kolejnych tygodniach" ${ }^{46}$, przy czym bardzo starannie odtwarza w pamięci tych kilka upalnych tygodni, które spędził na tytułowej wyspie w towarzystwie niezwykłego bliźniaczego rodzeństwa. Milan i Milena byli jego przewodnikami po ich starym wielkim domu i cmentarzu nocą, ale też uczyli go rozpoznawać smak rozkoszy, miłosnego niepokoju i wchodzenia w dorosłość. Z kolei Nelle Leibert z Katzenberge uda się sama w pełną tajemnic (motyw kainowego zabójstwa) podróż na wschód, by w Ukrainie poznać prawdę o swoim polskim dziadku, wysiedlonym z Wołynia na tzw. Ziemie Odzyskane.

Obie autorki mają migracyjne pochodzenie, przy czym Schulz wyjechała do Niemiec w 1989, a Janesch urodziła się tam w 1985 roku, ponieważ matka nie wróciła z urlopu w RFN, gdy w Polsce nastał stan wojenny. Odpowiednio do faktów biograficznych różną postać przyjmuje w tych dwóch utworach migracyjność. W powieści młodszej Janesch widać ją m.in. w eksploatowaniu problemów, jakie wiążą się z podwójnym pochodzeniem odautorskiej bohaterki, samodzielnie poszukującej prawdy o swoich kresowych korzeniach: dla Niemców jest Polką, a dla Polaków Niemką. Ta emigracyjna wprawa nie gwarantuje jednak pisarce wyjścia w Katzenberge, zauważa Aleksandra Burdziej, poza wyraźnie schematyczne postrzeganie jej polskich rodaków, podobnie zresztą jak Niemców, a także Ukraińców ${ }^{47}$. Z kolei motyw brutalnego usamodzielniania się, przekraczania różnych, erotycznych i rodzinnych, tabu oraz niestandardowej inicjacji seksualnej - czyli świat wykreowany przez Schulz w Das Eiland, pozwala spojrzeć na jej utwór, twierdzi Hans-Christian Trepte, jak na dowód „pożegnania z polskością" ${ }^{48}$.

46 P. Schulz Das Eiland, s. 35.

47 A. BurdziejZperspektywy niemieckich wnuków. Przełamanie tabu w pamięci rodzinnei jako droga do odnalezienia własnejtożsamości w powieści „Katzenberge"Sabriny/anesch, w: Opcja niemiecka..., s. 158-159.

48 H.-Ch. Trepte Centra i peryferie w literaturze polskiej XX i XXI wieku - uwagi polonisty niemieckiego, w: Centra-peryferie w literaturze polskiej XX I XXI wieku, red. W. Browarny, E. Rybicka, D. Lisak-Gębala, Universitas, Kraków 2015, s. 73-76. 
Niemniej aura niesamowitości wiąże się w obu narracjach zarówno z bohaterami, jak i z niezwykłymi miejscami, w których działają. Dlatego do głosu dochodzi tu też przyroda, która pełni funkcję wzmacniającą to, co trudno wyrażalne (niepokój, napięcie, strach, ciekawość Johna i Nelle). Podczas gdy Sabrina Janesch, zgodnie z liniową kompozycją swej powieści, pokazuje m.in. graniczną (według pisarki) rzekę Bug, a następnie gęste ukraińskie lasy, Schulz niejako punktowo rozbudowuje sferę niesamowitości tytułowej wyspy; piętnastoletni bohater ogląda morze, piach i wydmowe lasy, które umożliwiają mu bardzo zmysłowe doświadczanie świata.

Obie pisarki sięgają też po elementy obcych dla protagonistów kultur, co dopełnia wrażenia niesamowitości miejsc i sytuacji, w jakich znaleźli się John i Nelle. Słowiańska ludowość, niszczące plotki, lokalne legendy, wierzenia i czary przewijają się na kartach Katzenberge:

Po tym, gdy rankiem Janeczko wyszedł z domu, Maria rozrobiła miksturę, a następnie rozlała ją wokół domu i na podwórzu. Po kropelce, thumaczyła później Janeczce, bo jeśli by za dużo tego płynu spadło na ziemię, nigdy by już na niej nic nie wyrosło. Swoje włosy musiała zaś spalić, żeby powstały z nich popiół dodać do wywaru z marzanki wodnej. ${ }^{49}$

Natomiast u Schulz, oderwanej w Das Eiland od bezpośredniego kontekstu migracyjnego, taką funkcję pełni np. ponadetniczna, wielokulturowa symbolika bliźniąt jednojajowych oraz elementy wudu:

Kult bliźniąt spotykany jest w różnych częściach świata, w rozmaitych kulturach. Jednak w wudu występuje kult bliźnięcia męskiego i żeńskiego. Ona nazywa się Mawu, a on Lisa. Oboje symbolizują przeciwstawne energie: męską aktywność i żeńską bierność, Słońce i Księżyc, agresję i delikatność, to, co jasne i to, co ciemne. Razem stanowią obojnackie bóstwo, hermafrodytę, kosmiczną jedność. ${ }^{50}$

W takim uniezwyklonym otoczeniu tabu główna oś obu utworów jest niczym fatum, które ciaży nad postaciami i które chcą one rozbroić na własny sposób.

Prywatny charakter doświadczeń własnej migracyjności wydobywają też Alexandra Tobor i Tomasz Kwiatkowski. W przypadku tych autorów czerpanie

49 S. Janesch Katzenberge, s. 142 [przeł. - M.Z.-W.].

50 P. Schulz Das Eiland, s. 61 [przeł. - M.Z.-W.]. 
z konwencji niemoźliwego stanowi formę ekspresji przeźyć o silnie osobistym charakterze. Formalnie ich utwory różnią się pod każdym względem: książka Tobor, Sitzen vier Polen im Auto. Teutonische Abenteuer, jest powieścią utrzymaną w ironicznej konwencji baśni ${ }^{51}$,Krychaz rodu Dawida - Londyn. Dwa Amsterdamy ${ }^{52}$ zaś reprezentuje autobiograficzne, miejscami nieco prozaizowane świadectwo o popularnym charakterze: byłem - przeżyłem - opowiem. Ale niezależnie od tych głębokich różnic gatunkowych obserwujemy w obu książkach, jak osobiste doświadczenie bohaterów wysuwa się tu na pierwszy plan, wspomagane wykorzystaniem konwencji niemożliwego.

I tak autobiograficzne doświadczenia Alexandry Tobor: pierwsze trudne etapy emigracyjnego pobytu z rodzicami i bratem w obozie dla przesiedleńców oraz próby odnalezienia się w zupełnie obcym świecie zostają po latach, przez debiutującą tym materiałem pisarkę, przerobione na specyficzną baśń. Ośmioletnia Ola, narratorka powieści, przeżywa nie specyficzny koszmar obozowego życia w Unna-Massen, którego doświadczyli np. młodzi mężczyzni w książkach Muszera i Niewrzędy, ale swą wielką dziecięcą przygodę - wszystko ją zadziwia, a wiele zachwyca. W zderzeniu z realiami obozu dziewczynka wytwarza własny świat i dlatego w codziennych wydarzeniach widzi sytuacje magiczne, a zastaną rzeczywistość zaklina i czaruje. Tymi właśnie metodami bohaterka pomaga sobie w przyswojeniu emigracyjnych faktów i takim teź sposobem Tobor objaśnia odbiorcy wykreowany w opowieści świat. Sitzen vier Polen im Auto nie jest jednak naiwnym opowiadaniem dziecka, a pełną ironii stylizacją, w czym też czytelnicy rozpoznają dystans dorosłej autorki ${ }^{53}$. Widać to doskonale, gdy np. groteskowy charakter zajścia w supermarkecie (ojciec robi dzieciom zdjęcia na tle regału z zelkami Haribo, a matka od nadmiaru wrażeń omdlewa) rozrzedza narratorka konwencją baśniową: sklep Aldi zmienia się tu w Alladyna, a wrota skarbca otwierają się samoistnie:

Wtedy wydarzyło się coś magicznego: szklane drzwi, które prowadziły do wnętrza supermarketu, otworzyły się jak za dotknięciem czarodziejskiej różdżki. Jak to było możliwe? Jeszcze wcale nie weszłam do środka, już wybiegałam na zewnątrz. Drzwi zamknęły się. Powoli podeszłam do nich

A. Tobor Sitzen vier Polen im Auto. Teutonische Abenteuer, Ullstein Buchverlage, Berlin 2012.

T. Kwiatkowski Krycha z rodu Dawida - Londyn. Dwa Amsterdamy, Piktor, Łódź 2007.

53 Piszę o tym szerzej w: "Inny to ten, który wtaśnie siedzi w aucie". Prozatorski debiut Alexandry Tobor a nowe pokolenie piszq̨cych o Polsce w Niemczech. 
znowu. „Sezamie, otwórz się”, rozkazałam, ale sezam był szybszy. Ponownie wbiegłam do środka $[\ldots]^{54}$

O czarowaniu i tym samym braniu w nawias trudów początków emigracji nie ma mowy w drugiej z zestawianych tu narracji - książce Tomasza Kwiatkowskiego. Oddanie prawdy pomyślał autor jako dosłowną relację z tego, jak było naprawdę w pierwszych tygodniach jego emigracyjnego pobytu w Londynie. Werystyczne nastawienie nie oznacza bynajmniej rezygnacji z pierwiastka niesamowitego. Okazuje się bowiem, że w emigracyjnej zwykłości nietrudno o dziwactwa, „przegięcia” i hiperbolizacje, szczególnie kiedy jest się wśród swoich, w emigranckich gettach na Wyspach. Upostaciowieniem strasznego, das Unheimliche, jest tytułowa Krycha, starsza, siwa Polka wyglądająca na kloszardkę, właścicielka hotelu, w którym zatrzymują się emigranci.

Każdy rozdział książki zawiera solidną dawkę informacji o bohaterce, ale narrator raz po raz sygnalizuje, że to jeszcze nie wszystko, i przygotowuje czytelnika na jakieś znaczące „więcej”: „No cóż, sprawy przybrały trochę niekorzystny obrót, to prawda, ale gdyby nie to, nie miałbym okazji wyjaśnić do końca, jak się naprawdę sprawy mają z tym «hotelem» i Krychą"55.

Krycha jest postacią-soczewką skupiającą przerośnięte do granic ludzkie przywary: skąpstwo, matactwo, niechlujstwo, zakłamanie, niegodziwość, złośliwość, hipokryzję i bezduszność (chorego na Alzheimera męża zostawia często głodnego, zabrudzonego i bezbronnego). Wszystko to zaś, jak przekonuje narrator, łączy się z osobliwą, żarliwie manifestowaną religijnością starszej pani, która ma rzekome kontakty z Jezusem powołującym ją do pełnienia misji w Londynie. W kolejnych partiach wspomnień, noszących symptomatyczne w tym kontekście tytuły (Gośćw dom, Dobra samarytanka, Krystianizm, Judasz ), poznajemy ją jako nawiedzone skąpiradło:

- Mam cię - ryknęła jak lew. - Chciałeś uciec cichcem, jak złodziej! Natychmiast oddawaj pieniądze, które mi jesteś winien! - krzyczała, szarpiąc go za rękaw i machając mu przed nosem kartką, na której widniał szczegółowy wykaz nieuregulowanych należności za hotel.

Ona zresztą miała wszystkich tak opisanych, dzień po dniu, ile każdy powinien, według jej abstrakcyjnej stawki, dopłacić.

54 A. Tobor Sitzen vier Polen im Auto..., s. 101 [przeł. - M.Z.-W.].

55 T. Kwiatkowski Krycha z rodu Dawida..., s. 92-93. 
- Jezus mi powiedział, że chcesz uciec! Dostałam od Niego znak, że to będzie akurat dziś i do tego teraz! - naciskała. ${ }^{56}$

Funkcjonowanie hotelu przy Elms Rod, który według zamysłu właścicielki niczym arka ma pomagać emigrantom potrzebującym wsparcia, przeczy wszelkim zasadom tzw. normalności. Mieszkać tam jest tak strasznie, że aż niesamowicie. Dlatego na poparcie swoich zapisków o machlojkach Krychy i by uprzedzić ewentualne niedowierzanie czytelników, autor stwierdza np.: „Szkoda, że nie przyjrzałem się wtedy temu listowi, bo bym go wziął od niej, skserował i ujawnił mistyfikację, a kopię załączyłbym do książki"57.

Zestawione ze sobą przekazy Kwiatkowskiego i Tobor pokazują, że na emigracji łatwo o niemożliwe i że można z niego zrobić użytek w tak odmiennych ramach gatunkowych, jak powieść i paradokumentalne świadectwo. Wymowna jest w tym kontekście metagatunkowa uwaga, jaką autor Krychy z rodu Dawida... zamieszcza w postowiu:

Książa ta nie jest może dziełem literackim. Chodziło mi raczej o użyteczność informacyjną. Jest jakby sprawozdaniem z pewnych zdarzeń, które miały miejsce w Londynie w 2004 roku. Ja to wszystko widziałem, zapamiętałem i spisałem. Komentarz zostawiam tym, co to będą czytali. ${ }^{58}$

Niezależnie od różnic między narracjami Kwiatkowskiego i Tobor widzą oni w sytuacji, w której się znaleźli, silny element niezwykłego. Koncentrując się na tym, co „wręcz niemoźliwe”, gromadzą świadectwa dziwności, by w ten sposób nieco ujarzmić zrazu obcy im i zaskakujący ich świat. Bogata wyobraźnia Oli pozwala jej pełnić rolę dziecięcej królowej opowieści, Kruk (ksywki bohaterów polskiej prozy w Anglii to sprawa wymagająca osobnej uwagi) zaś, opisując straszną Krychę przez podanie wielu bardzo szczegółowych zdarzeń z jej udziałem, stara się być ponad to, zapanować nad przykrą przygodą, jaką jest przymus przebywania w jej hotelu.

Czy opisana tu w ramach wstępnego rozpoznania konwencja ma walor transformacyjny wobec literatury e-migracyjnej ? Prozatorskie teksty z tego klucza zawsze były bogate w fakty związane z przemieszczaniem się autorów

\footnotetext{
56 Tamże, s. 59-60.

57 Tamże, s. 143.

58 Tamże, s. 157.
} 
i bohaterów i zawsze szukały też nowych literackich sposobów, by realność tę udostępnić w atrakcyjnej formie czytelnikom. Jakkolwiek tendencja do uniezwyklania wydarzeń bezpośrednio wynikających z migrowania jest tu bardzo czytelna, to sfera znaczeń ściśle emigracyjnych wydaje się w tych utworach donioślejsza.

Gatunki literatury popularnej pełnią w prezentowanych książkach funkcję rozpoznawalnego porządku, który sprzyja tworzeniu rezerwuaru danych opisujących określone zjawiska kulturowe $\mathrm{e}^{59}$, w tym tak charakterystyczny dla literatury popularnej, ale w nie mniejszym stopniu dla literatury emigracyjnej - podział świata przedstawionego na swoich i obcych. Innymi słowy, niemożliwe jako konwencja, sposób artykulacji doświadczeń autorsko-narratorskich wydaje się podporządkowane sferze emigracyjnej. Inwazja świata niezwykłego i niesamowitego w taką codzienność nie podważa jej ciężaru, a niedopowiedzenia i struktura niekompletności nie osłabiają znaczeń związanych z opuszczaniem jednego miejsca i zamieszkiwaniem w innym. Nawet odrębna, wyzwolona z polskości i obowiązków wobec niej, jak chce niemiecki slawista $^{60}$, narracja Pauliny Schulz może być w tym kontekście wyrazistym gestem oporu pisarki wobec tego, do czego przyzwyczaiły nas jej wcześniejsze utwory, ale może teź świadczyć o zamieszkaniu w niemczyźnie.

Skutkiem tego do każdego ze wskazanych tekstów można by dodać przymiotnik "e-migracyjny" jako przydawkę gatunkująca. W ten sposób otrzymalibyśmy: emigracyjną baśń, migracyjną powieść o wpędzeniach, emigracyjny thriller i migracyjny kryminał. W przypadku utworu Adama Miklasza, od którego zaczęłam ten artykuł, sam autor ułatwia nam sprawę i w podtytule swojej Polskiej szkoty boksu dopisuje, że to Powieść emigracyjna.

R. Sendyka Wstronę kulturowej teorii gatunku, w: Kulturowa teoria literatury..., s. 276.

60 H.-Ch. Trepte Centra i peryferie w literaturze polskiejXXiXXI wieku... 


\section{Abstract}

\section{Małgorzata Zduniak-Wiktorowicz}

ADAM MICKIEWICZ UNIVERSITY (POZNAŃ)

EUROPEAN UNIVERSITYVIADRINA

Other Emigrations? (Im)Possible Encounters of Polish Prose Written in Germany and the UK

The article asks whether the most recent 'Polish-German' and 'Polish-British' prose by Polish emigre writers is keeping up with literary scholarship and its conspicuous preference for the paradigm of migration over emigration. Zduniak-Wiktorowicz looks at several younger Polish writers working in Germany and England (such as Magdalena Parys, Paulina Schulz, Alexandra Tobor, Jan Krasnowolski and Adam Miklasz) to produce a comparative account of both the circumstances of their emigration and their literary work. She demonstrates that authors born in the 1970 s and 1980 s draw on literary conventions that have never before been used on such a massive scale in this type of Polish prose. Her corpus includes the action novel, thriller, political thriller, detective novel, and themes related to these genres, such as mystery, taboo, or overcoming cultural conventions.

\section{Keywords}

emigration, migration, young writers of Polish descent in Germany, Polish prose in the UK, popular literature 